\title{
BUBBLE PRESSURE IN GREENLAND ICEBERGS
}

\author{
By P. F. Scholander \\ (Zoophysiological Institute, University of Oslo and Scripps Institution of Oceanography, \\ University of California, La Jolla, California) \\ and D. C. NutT \\ (Department of Geography, Dartmouth College, Hanover, N.H.)
}

\begin{abstract}
A simple technique for measuring the pressure in individual bubbles of gas in glaciers is described. By this technique, bubble pressures in twenty-six west Greenland icebergs were measured. The bubbles were for the most part tubular in shape and oriented parallel, lending a fibrous and sometimes stratified appearance to the ice. Various suggestions are offered for the formation of these bubbles. Most bubbles had a pressure of 4-5 atmospheres, and pressures as high as 20 atmospheres were recorded. In closely adjacent bubbles differences of 2-5 atmospheres were often measured, which indicated diffusion tightness and lack of plasticity in the ice. When the ice surface melts, the bubbles expand at the cost of water extrusion. The various factors contributing to the maintenance of vertical walls characteristic of tabular bergs are discussed.
\end{abstract}

RÉsumé. On décrit une méthode simple qui permet de mesurer la pression à l'intérieur des bulles de gaz dans les glaciers. En employant cette méthode on a obtenu des évaluations de la pression à l'intérieur des bulles de vingt-six icebergs dans l'ouest du Groenland. Les bulles étaient pour la plupart de forme tubulaire et d'orientation parallèle, ce qui prêtait à la glace un aspect filamenteux et parfois même stratifić. Plusieurs explications possibles sont avancées sur la formation de ces bulles. Dans la plupart des bulles on a trouvé des pressions de 4 ou 5 fois celle de l'atmosphère, et l'on a constaté des pressions que atteignent 20 atmosphères. On a souvent observé des divergences de 2 à 5 atmosphères dans des bulles très rapprochées l'une de l'autre, ce qui semble indiquer que la diffusion ainsi que la plasticité sont presque négligeables dans cette glace. Au moment de la fusion de la glace superficielle, les bulles se dilatent au détriment de l'écon!lement de l'eau de fonte. On discute les divers facteurs qui concourent à maintenir les falaises abruptes qui constituent les limites des icebergs tabulaires.

Ztsammenfassung. Es wird ein einfaches Verfahren zur Druckmessung in Gletschern vorhandenen individuellen Gasblasen beschrieben. Nach diesem Verfahren wurden Gasblasendrucke in 26 Eisbergen Westgrönlands gemessen. Die Blasen waren in der Hauptsache röhrenförmig und waren parallel gelagert, so dass sie dem Eis eine faserartige und manchmal schichtenförmige Erscheinung verliehen. Für die Entstehung dieser Blasen werden verschiedene Vorschläge gemacht. Die meisten Blasen wiesen einen Druck von 4-5 Atmosphären auf, und Drucke bis zu 20 Atmosphären wurden registriert. In nahe benachbarten Blasen wurden oft Unterschiede von 2-5 Atmosphären gemessen, was auf Diffusionsdichte und Mangel an Plastizität im Eis schliessen liess. Wenn die Eisoberfläche schmilzt, erweitern sich die Blasen auf Kosten der Wasserausstossung. Die verschiedenen Faktoren, die zur Erhaltung von Vertikalwandkennzeichen plattenförmiger Berge beitragen, werden besprochen.

\section{INTRODUCTION}

Most of the icebergs drifting in the sea are shining white, but, especially in the fjords near the outlet glaciers, smaller bergs are frequently found which are bluish in color. The whiteness of the typical bergs is caused by tiny gas bubbles evenly distributed throughout the ice, whereas the blue ice is clear and nearly bubble free.

When a small piece of white ice is put into a glass of water it fizzes as it melts; and through a lens one may see the gas popping out under pressure as the enclosures melt open. As one cruises slowly through the brash of an active glacier or among calving icebergs, one hears a much louder crackling sound evidently caused by stress fracturing of smaller pieces. And in the icefjords and areas where new bergs are found, loud reports like gunfire are often heard from icebergs evidently undergoing large internal stress adjustments. Another characteristic of this white iceberg ice which is caused by the gas pressure is the ease with which it flakes apart when struck by an ice axe or chisel. In contrast, fractures in clear ice have a tendency to stick together, displaying Newton bands of color.

The origin of the gas which lends these characteristics to the white glacier ice is atmospheric air which was trapped between the snowflakes when these compacted into ice under the ever-increasing burden of falling snow. At a certain depth these air spaces close off from 
each other, forming irregular cavities of fairly uniform size and distribution. Already at this early stage Schytt ${ }^{\mathrm{I}}$ found them to have acquired rounded corners, and Langway, ${ }^{2}$ observing cores from drillings in the Greenland Ice Sheet, found that as one goes deeper into the ice the cavities gradually approach sphericity. The reason for this, one may assume, is that the walls of the cavities are being constantly remolded by a process of evaporation-sublimation, which will reach a steady-state equilibrium only when the vapor tension is the same throughout the cavity. Under uniform conditions, this will result in spherical bubbles.

When after perhaps thousands of years of transport through marginal ice rivers and outlet glaciers the ice finally floats off into the ocean as bergs, we find that the bubbles are very different, usually hair-fine tubes which through their parallel arrangement give the ice a fibrous or grainy appearance. Sometimes the graininess is stratified, suggesting the persistence of seasonal or meteorological layers. Bergs with spherical bubbles occur, but are less common.

The amount of air trapped in the ice is usually some 4-9 per cent of the ice volume when measured at one atmosphere pressure, but the density of the glacier ice increases with depth and approaches asymptotically that of pure ice, i.e. the cavities become compressed by the weight of the ice. At the depth of some $3_{1} 6 \mathrm{~m}$., Langway ${ }^{2}$ found the gas pressure to reach nearly 30 atmospheres, and in general the gas bubbles were seemingly compressed appreciably less than would be expected from the weight of the overlying ice and snow. The discrepancy amounted to some 3-5 atmospheres, but is probably less than this because some gas loss from micro-cracking of the cores inevitably takes place. This indicates a certain lack of plasticity of the ice, which, however, is more convincingly demonstrated by his density measurements. For when after a year's storage these were repeated, he found a relaxation of the ice above but not below io atmospheres bubble pressure.

The solubility of air in ice when measured at one atmosphere pressure and in ice colder than $-2^{\circ} \mathrm{C}$. is very low, if any, and this is also reflected by the extremely low diffusion rate of gases through ice. ${ }^{5}, 6$ At moderate pressures, therefore, and in cold ice one may expect that the air bubbles, although compressed and deformed, will preserve their identity of composition for a long time after originally having been closed off. To what extent this would apply also under the very great pressures at the bottom of the great polar ice sheets is not known.

The present investigation was performed during the Arctic Institute Greenland Expedition $195^{8}$ on board the Norwegian sealer M/S Rundøy. The main objective of the Expedition was the extraction of carbon dioxide from the gas enclosures for carbon-14 dating of ice discharged from west Greenland glaciers; but various other parameters of the gas bubbles were investigated, such as composition and pressures. Pressure determinations made on icebergs at several localities (Fig. I) are discussed below.

\section{METHOD}

The classical method by Hamberg 7 and later authors $1,2,3,8,9$ for the estimation of gas pressure in a piece of glacier ice is based on two measurements, (a) the specific gravity of the ice, and (b) the volume of gas liberated from the ice upon melting. When carefully applied in the laboratory, this method has yielded eminently useful results, but even so, it suffers from serious limitations. At high pressures the bubbles are compressed so the difference in density between glacier ice and bubble-free ice becomes only a small fraction of i per cent, which requires exacting instrumentation and temperature control in order to obtain useful density data. Likewise, loss of gases in melt water and kerosene are difficult to estimate accurately. A further limitation is that high-pressure ice develops a criss-cross pattern of micro-cracks which relieves the pressure in all the bubbles which are hit, so the average pressure will appear too low.

The technique involving melting under mercury and independent determination of the 
free and dissolved gas, used by Scholander and others, ${ }^{\mathrm{IO}}$ or the "cold" extraction of gas by shaving down the ice under vacuum by Coachman and others 4 are cumbersome and still limited by the need for accurate density measurement. Bader ${ }^{\mathrm{II}}$ and Nakaya ${ }^{\mathrm{I}}$ made measurements of pressure in individual spherical bubbles. Their techniques are encumbered by solubility errors, and are not usable for the long tubular bubbles characteristic of the Greenland icebergs.

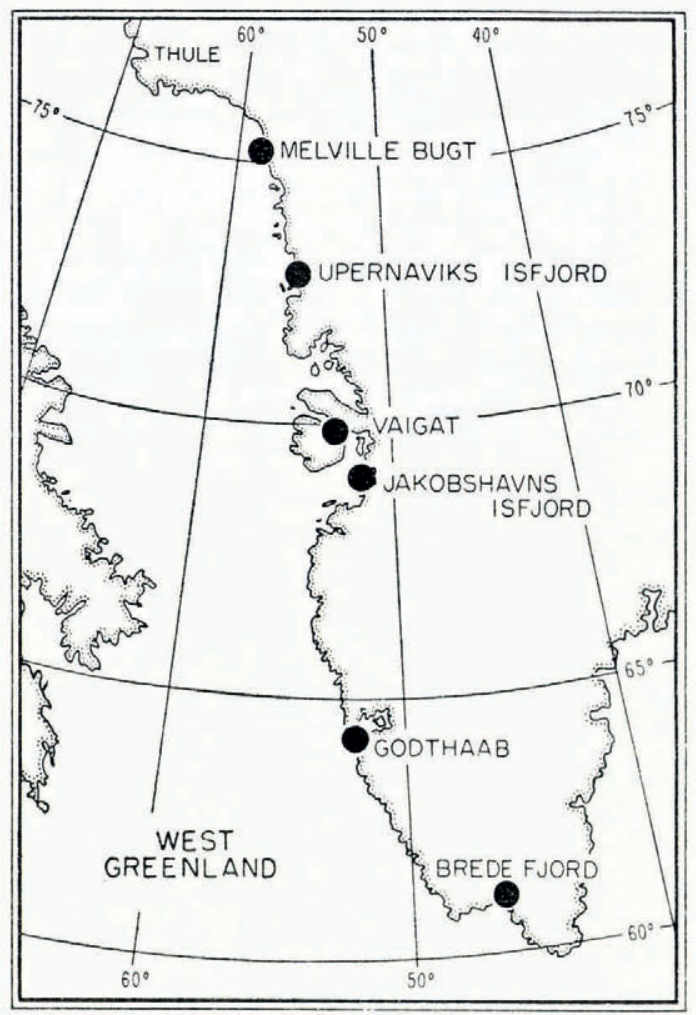

Fig. I. Geographical location of sampling areas

After a series of unsuccessful attempts in the ship's laboratory to obtain satisfactory results with the classical approach, a new method was developed which permits the measurement of gas pressure in individual bubbles. The method has the advantage that its accuracy on a per cent basis is as good at high pressures as at low, and it is well suited to field work.

\section{Principle}

A piece of ice is placed in a pressure chamber filled with cold glycerine solution which is concentrated enough to effect a progressive surface melting while maintaining the ice below freezing. At the moment the gas bubble under observation breaks through the cavity, the hydrostatic pressure in the chamber is adjusted so that the water meniscus becomes flush with the opening. The pressure of the gas is then equal to the hydrostatic pressure of the chamber.

\section{Instrument}

The instrument was built in the machine shop of the ship from porthole windows and other available materials. It consisted of a pressure chamber and conventional Bourdon 
pressure gauge connected to a hydraulic pump which was operated by an O-ring-sealed, screw-activated piston. The top of the chamber could be closed by means of a heavy glass window and O-ring seal (Fig. 2). Melting was observed through a low-power dissecting microscope. The whole assembly was placed on a piece of heavy plywood resting on top of a softly inflated automobile inner tube, which eliminated the various shipboard vibrations.

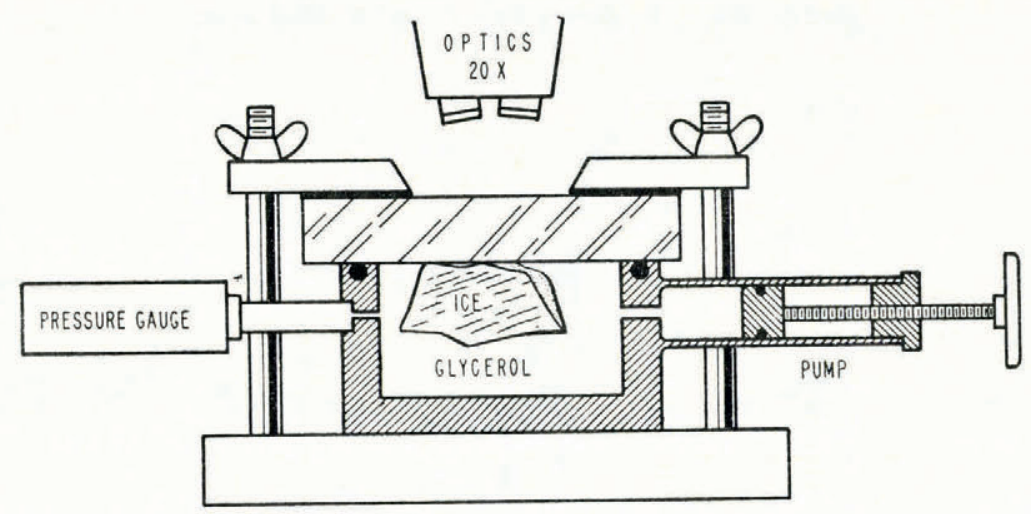

Fig. 2. Hydraulic pressure chamber for determination of gas pressure in single bubbles

\section{Procedure}

The ice is kept well below freezing by storing it in a bucket resting in an ice-salt mixture. The pressure chamber is filled with a 20 per cent glycerol solution chilled to $0^{\circ} \mathrm{C}$. A piece of ice from the storage bucket is rapidly cut into shape and placed in the chamber. The cover is clamped on, letting the glycerine overflow. By tilting the chamber, the ice piece is so oriented that the gas tubes (in side view) or round bubbles can be observed through the binocular when they melt open. When this happens a string of gas bubbles is ejected. The hydrostatic pressure is increased until it very nearly matches the bubble pressure, i.e. so that the gas meniscus pops in (or out) only very slightly when the bubble melts open. The meniscus is immediately adjusted flush with the opening, and the pressure read on the gauge (Fig. 4). With round bubbles it is necessary that the break-through pressure be slightly less than the bubble pressure, so glycerine does not enter the cavity on break-through.

\section{Accuracy}

When the system is kept cold there is melting only at the glycerine-ice interface, and there is no error from gas being dissolved in melt water inside the bubbles. Especially in the long fibrous bubbles the pressure can then be measured within a few per cent of the total pressure. But because of the considerable variations found from one bubble to the next, our present readings were made only to the nearest half of an atmosphere.

\section{Results and Discussion}

By this method, pressure measurements of gas bubbles were made from 26 icebergs or large pieces of floating glacier ice obtained from different locations along the west coast of Greenland from Brede Fjord (lat. $6 \mathrm{I}^{\circ}$ N.) to Melville Bugt (lat. $75^{\circ}$ N.) (Fig. I).

\section{Bubble dimensions}

The dimensions of the bubbles from most of the ice pieces where pressure was measured are given in Figure 3. It will be seen that most bubbles are tubular and range from some $0.02-0.18 \mathrm{~mm}$. in diameter and up to $4 \mathrm{~mm}$. or more in length. There is in our data no 

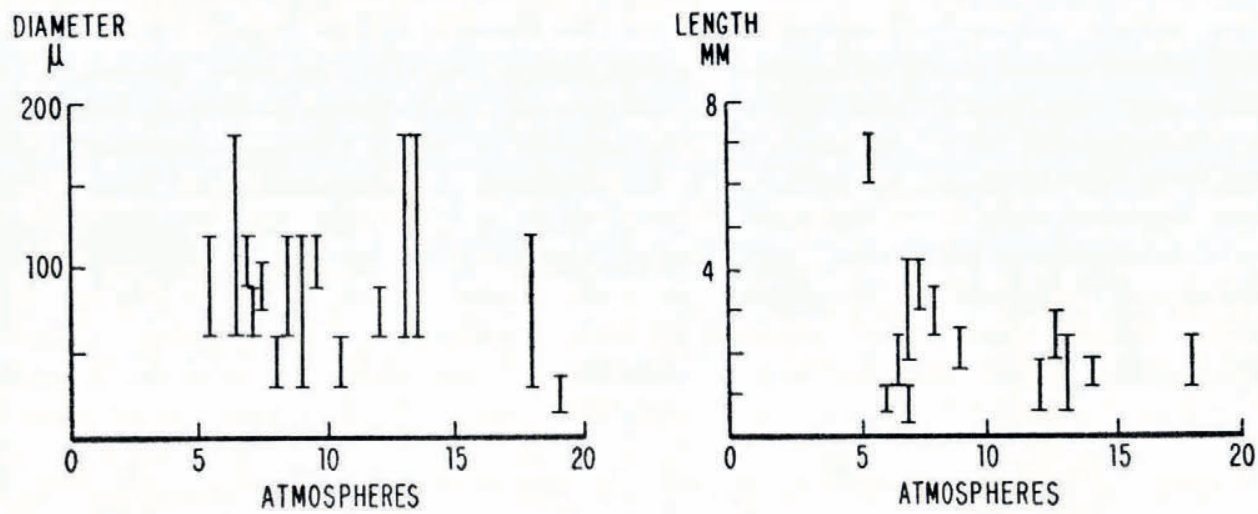

Fig. 3. Bubble dimensions in Greenland icebergs. Vertical lines give total variation in measurement from each tested piece of ice

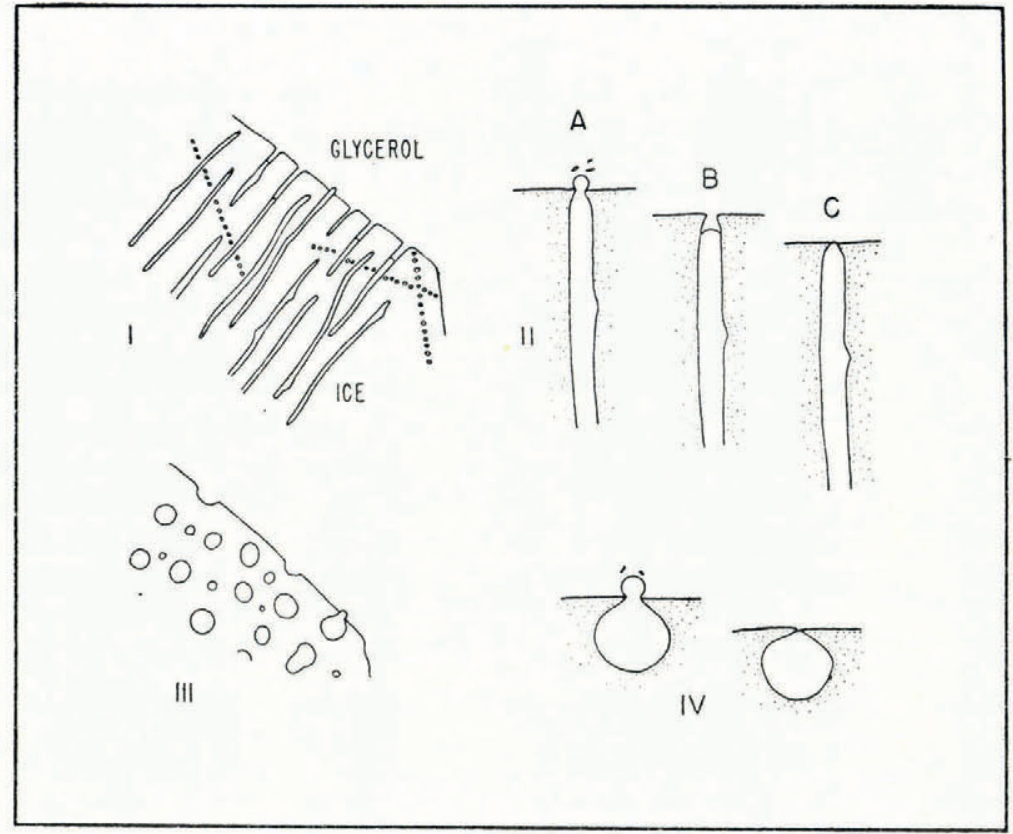

Fig. 4. I. Tubular bubbles melting open by the glycerol. Rows of fine bubbles indicate microscopic crack planes

II. A. Bubble bursting through ice when chamber pressure is slightly lower than bubble pressure

$B$. Chamber pressure adjusted slightly too high

C. Chamber pressure equals bubble pressure

III. Ice with round bubbles melting open in the chamber

$I V$. Round bubble popping through melting ice wall when chamber pressure is slightly low. To the right, bubble pressure matches chamber pressure

apparent correlation between bubble dimensions and pressure, although by and large such would be expected.

The round bubbles ranged from microscopic to $2 \mathrm{~mm}$. in diameter in white ice, but could reach several centimeters in blue ice. 


\section{Fressure in single bubbles}

It can be seen (Fig. 5) that there are bubble pressures in the different bergs from 2-3 to some 20 atmospheres, but the pressure range is nearly the same for each berg, regardless of sample location. It is remarkable that in each little piece of ice there is considerable $(2-5$ atmospheres) variation even among closely spaced individual bubbles. The clear ice which often comes floating up from the bottom level of the glacier front covered with sand, silt and stones contained bubbles with generally lower pressure (2-9 atmospheres).

The majority of the samples of white ice had a bubble pressure in excess of 4 to 5 atmospheres, but in practically all samples many individual bubbles occurred which had only atmospheric or near atmospheric pressure. Seemingly these bubbles had lost their pressure, and the reason for this became apparent from the following observations on the high pressure (20 atmosphere) berg encountered in the Vaigat (Fig. 5). This berg had a very hard and plane surface, which on closer inspection revealed a finely reticulate pattern of very fine surface cracks, looking to the naked eye somewhat like the cracked enamel on old china. Under the microscope one could see that the cracking planes usually extended at an angle to the tubes, and that each plane contained a fine spray of tiny bubbles of very uniform size and distribution, as indicated in Figure 4. Apparently these were stress cracks at the surface, which had been injected by gas from the severed tubes. This was confirmed by measuring the pressure in the tubes. In every case where a tube was crossed by such a plane it had lost its pressure, whereas adjacent tubes which had not been hit had their full pressure (Fig. 4).

\section{Integrity of individual bubbles}

There can be little doubt that individual bubbles can be preserved for a long time. This may be inferred from the extremely low, if any, diffusion through ice at cold temperatures as found by Scholander and others 5 and Hemmingsen. ${ }^{6}$ And it is very striking that closely spaced individual bubbles can preserve pressure differences of as much as 2-5 atmospheres such as described above. This indicates a considerable diffusion tightness and lack of plasticity in the ice.

From Hemmingsen's ${ }^{6}$ studies of the diffusion rate of carbon dioxide through ice in relation to temperature, it seems rather clear that what little gas can penetrate through the ice follows intercrystalline liquid brine films. The volume of such films would vary inversely to the temperature below freezing, and increase rapidly when the temperature approaches $0^{\circ} \mathrm{C}$. This would facilitate diffusion at higher temperatures, but at very high pressures one cannot disregard the possibility that the gas could be accepted into the ice lattice itself and again arise de novo when the pressure is relieved. But this is unknown, as indeed is the relation of gas bubbles to the processes of recrystallization which occur in ice.

\section{Formation of tubular bubbles}

The above considerations are tied in with the problem of how the tubular bubbles are formed which we find as a regular feature of most Greenland icebergs. Possibly they could have been produced from originally round bubbles by flow stresses, but in that case one must ask what is the meaning of the stratification which is occasionally seen? If such stratification were seasonal or meteorological, how could it survive a process which would stretch the original round bubbles out into long, filamentous tubes? Another possibility is that one is dealing with a certain equilibrium condition. If, namely, for some structural, thermal, or other reason the vapor tension is higher in one direction than in the other, the result will be tubular cavities rather than round bubbles.

\section{Effects of melting}

When fresh pieces of high-pressure fibrous ice were left lying on the deck they soon whitened, and similarly, it was often noticed that the fresh fracture area left on a berg after 
a calving was slightly darker than the surroundings, but soon whitened up in the sunshine. If a freshly hewn piece of old fibrous ice was left to warm up under the microscope, the tubes could be observed swelling and breaking up into separate bubbles which soon enlarged greatly, obviously at the cost of migration and extrusion of water from the ice.*

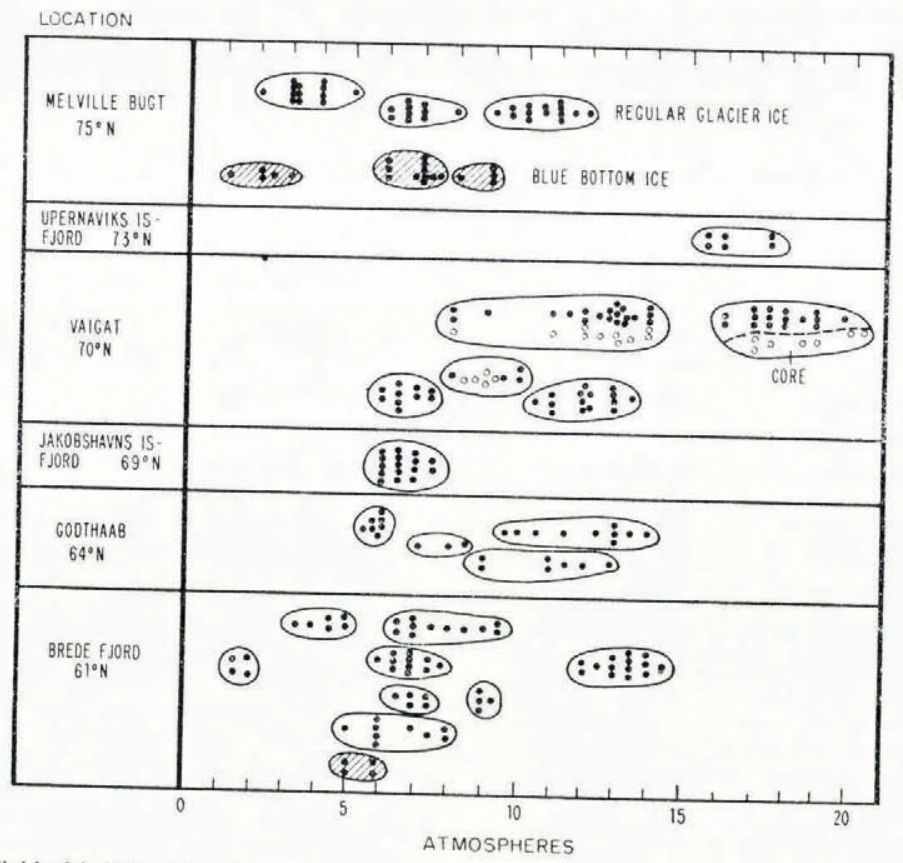

Fig. 5. Pressure in individual bubbles taken from various icebergs. Each point represents the pressure measured in a single bubble. A line is drawn around all measurements taken from the same iceberg. In two instances a second sample was taken from from a depth of one meter for comparison with the from the first, and in one case a second sample was taken by corer Pressure measurements were made on the bubbles the surface sample. These duplicale samples are indicated by open dots. indicated by shading

\section{Vertical walls of icebergs}

A conspicuous feature in large tabular icebergs is the vertical or even slightly overhanging walls which they present toward the water. These walls are of such regular occurrence that clearly they must be self-maintained by processes which disintegrate the berg. High pressure gas inclusions contribute to the easy fracturing of the ice, which is subjected to severe stress in the outer layers due to the large thermal gradient arising during the summer. Surface cracking, combined with bubble expansion and water extrusion, contributes to the weakening of the shell and further creation of stress differentials. Thus a surface disintegration takes place with a flaking off from a steep surface. But the melting of ice is much faster in the sea than in the air, so icebergs become rapidly undercut to the extent of a meter or more at the water line. The combination of progressive surface disintegration and the continual undercutting of the water line provides a natural explanation for the vertical walls.

As one looks at a tall, vertical ice wall $50 \mathrm{~m}$. or more high, one may wonder why this does not display a darkening or bluing of the ice from the top to the bottom as a consequence of

* Such loss of water by gas expansion was clearly indicated in earlier studies on Storbreen in Norway, where it was found that the more soluble components of the gas bubbles such as $\mathrm{O}_{2}$ and argon are lost preferentially
to $\mathrm{N}_{2}$ as one approaches the terminus of the glacier. ${ }^{13}$ 
compression of the bubbles. There seem to be two reasons for this. One is that such an effect would be masked by the relatively rapid whitening of the ice due to surface melting and bubble expansion, but another may be the rigidity of the ice, which will not readily respond to pressure differentials of even 2-5 atmospheres, such as indicated by the pressure differences observed in adjacent bubbles, and lack of relaxation under to atmospheres in Langway's ${ }^{2}$ studies on deep cores.

\section{ACKNOWLEDGEMENTS}

The work on which this paper is based was supported through the Arctic Institute of North America with primary funds from the Office of Naval Research (Contract Nonr-I I 38 (or), Projects ONR-229 and 240). The U.S. Air Force Cambridge Research Center contributed to the overall project. The Ministry for Greenland kindly granted permission to carry out the field studies in Greenland. Appreciation is expressed to these organizations for their assistance and cooperation.

We are much indebted to Professor Hans W:son Ahlmann, and to the late Professors Carl Rossby and H. U. Sverdrup for stimulating discussions of the overall project.

Special thanks is due to Mr. Odvar Iversen, who constructed the pressure measuring device from materials at hand on board the expedition ship M/S Rundøy.

MS. received 24 November 1959

\section{REFERENGES}

I. Schytt, V. Norwegian-Britisit-Swedish Antarctic Expediiton, I949-52. Scientific Results, Vol. 4, C, I958, p. I I 3-52. Associntion Iniernationate d'Hydrologie s: ientifique. Symposium de Chamonix, 1958, n. 336-49.

Shumskiv, P. A. Osnozy sinukturnogo ledovedeniya. Pelrografiya presnogo l'da kah mu cod glyatsiologicheskogo issledovaniya. Moscow, Izdatel'stvo Akademii Nauk SSSR, 1955. [French translation: Principes de glaciologie te la glace comme méthode d'étude giaciologique. Annales du Centre d'Études et de Documentation Paleontologiques, No. 22, 1957.]

4. Coachman, L. K. and others. Gas cuclosures in a temperate glacier, by L. K. Coachman, E. Hemmingsen, and P. F. Scholander. Tellus, Nol. 3, No. 4, 1956, P. 4i5-23.

5. Scholander, P. F... and others. Studies on the physiology of rozen plants and animal Compative Physiology, Vol. 42, Scholander, W. ilagg, R. J. Hock and L. lrving. Jotrnet c
Suppl. I, I053.

6. Henmingsen, E. Permeation of gases through ice. Tellus. Vol. Hal. Suenska Vetenskaps-Akademiens Handlingar,

7. Hamberg. 2, No. 2, 1895 , p. 3-13.

8. Bernard, C. Compte rendu de quelgne observations et experiences. Études Glaciologiques, 4, I922, p. 91 -171,

Werebnisse der dinischen Expedion nach Dronning 9. Koch, J. P., and Wegener, ג. Wissenschaftliche Ergebnisse der danischen Expediom Gronland, Bd. 75,
Louises-Land und quer über das Inlandeis von Nordgrönland ig12/13. Meddelelser om Grond Nr. 1-2, 1930.

10. Scholander, P. F., and others. Gases in iccbergs, by P. I. Scholander, J. W. Kanwisher and D. C. Nutt. Srience, Vol. 123, No. 3 186, 1956, p. 104-65.

II. Bader, H. The significance of air bubbles in glacier ice. Joumat of Glat melting. U.S. Snow, Ice and Permafrost

12. Nakaya, L. ìroperties of single crystals of ice, Research Establishment. Resecti Paper 13, 1956.

3. Coachman, L. K., and others. Gas loss trom a temperat
Scholander. Tellus, Vol. 10, No. 4, r958, p. 493-95. 